\title{
MODERNIZATION AND CHANGES IN KIAI-SANTRI RELATIONS IN THREE PESANTRENS IN JAVA
}

\author{
Yon Machmudi \\ Universitas Indonesia, Depok, Indonesia \\ E-mail: yonmachmudi@yahoo.com
}

\begin{abstract}
This study focuses on analyzing the changing role of kiai and his influences in pesantren. The decline of kiai's authority in pesantren, besides being resulted from the changing role of kiai, is caused by social changes outside pesantren. As a result, kiai, who initially served as the agent of change and political reference, is now experiencing some challenges. To analyze such conditions, this study carefully uses the concept of authority and the patron-client relationship between kiai and santri. In this case, the research is carried out in three pesantrens in Java; Pesantren Cidahu Pandeglang, Pesantren Husnul Khotimah Kuningan, and Pesantren Darul Ulum Jombang. Pesantren that has transformed into a modern institution tends to be more resilient, but the influence of kiai toward his santris starts to decrease. Meanwhile, pesantren that remains as a traditional institution has reduced in number, but the influence of kiai toward the santris is still strong. Thus, this study shows that the power of kiai toward santri in modern pesantren has decreased due to modernization and social changes.
\end{abstract}

Keywords: Pesantren; kiai-santri relations; authority; modernization.

\section{Introduction}

Pesantren is a unique cultural heritage of Indonesia. In some areas of Southeast Asia, such as Pattani, Thailand, and Kelantan, Malaysia, this dormitory-based religious education model is called "pondok." Pesantren is the oldest religious education institution in Indonesia and has contributed a lot to the development of Indonesian nation. This is because pesantrens as traditional Islamic educational institutions have the aim of understanding, living, and practicing Islamic teachings by making religious morals as a guide 
for people's lives. ${ }^{1}$ Various roles in society, both in the fields of education, economy, socio-religion, and politics, have been played by pesantren alumni. Pesantren generally comprises of three interrelated elements, namely, "kiai" as the main factor who builds the pesantren system, "santri" as students who studies various sciences in pesantren, and "pondok" or dormitory provided by the kiai to accommodate the santris. ${ }^{2}$ The interaction of these three elements then forms a unique and quiet subculture different from the life of the surrounding community, which Dhofier calls it "the pesantren tradition."

Kiai plays a vital role in influencing the education system that applies in pesantren and the behavior of santris. ${ }^{3}$ The position of kiai becomes very special as santris always follow the rules and recommendations made by kiai. Kiai is a figure who can dominate religious authority, which is usually followed by an obedient, even uncritical, attitude due to dogmatic spiritual understanding. ${ }^{4}$ For instance, a charismatic kiai can quickly mobilize his followers to obey whatever he wants. Thus, it is not surprising that kiai is considered a solidarity maker and becomes the target of political power holders. Kiai's authority and ability to dominate religious truths make it easier for kiai to mobilize masses to follow and imitate whatever the kiai does. The relation between kiai and santri becomes very special because they stay together in one complex and interact intensively every day. Santris always obey kiai even though they no longer stay in pesantren but in society. The relationship continues so that kiai becomes a source of reference for the community in determining their life choices. ${ }^{5}$

However, the authority of kiai has begun to be questioned in terms of its effectiveness in influencing the mass and directing

\footnotetext{
${ }^{1}$ Mastuhu, Dinamika Sistem Pesantren (Jakarta: INIS, 1994), 6.

2 Zamakhsyari Dhofier, Tradisi Pesantren: Studi tentang Pandangan Hidup Kyai (Jakarta: P3M, 1982), 28.

3 In fact, the modernization process in pesantren has changed educational system and patterns of relation between kiai dan santri. See Bashori, "Modernisasi Lembaga Pendidikan Pesantren Perspektif Azyumardi Azra," Nadwa: Jurnal Pendidikan Islam, Vol. 11, No. 2 (2017), 3-4.

${ }^{4}$ Haryatmoko, Dominasi Penuh Muslihat: Akar Kekerasan dan Diskriminasi (Jakarta: Gramedia, 2010), 3.

5 Samsul Nizar, Sejarah Sosial dan Dinamika Intelektual: Pendidikan Islam di Nusantara (Jakarta: Kencana Prenada Media Group, 2013), 95.
} 
political choice. The position and role of kiai have seemingly changed compared to that in the past in terms of their authority. Kiai, who acted previously as a cultural broker, have tried presently to play another role in politics. Many kiais then get involved in practical politics and become political brokers. The performance of kiai as a political broker is considered the cause of the decline of public trust in the figure of kiai.

The decline in the political influence that will be discussed in this article will undoubtedly become a debate because of the currently developing assumption that the role of kiai in society, both in the religious and political fields, is still solid and unshakable. According to Geertz, charismatic kiai is respected in his pesantren and has a vital position in society. Kiai carries out his functions as intermediaries for the community to solve such daily problems they face as personal, family, work, marriage, health, even political choices. ${ }^{6}$ The role of kiai in society is so decisive that this figure has a unique position and invites many parties to approach him. Thus, kiai becomes a reference for the surrounding community in determining the life choices faced.

According to Karl D. Jackson, kiai as religious leaders has a charisma called traditional authority. This authority comes from the process of interaction between individuals and groups by which a kiai can easily influence his followers. ${ }^{7}$ Not only do Islamic parties have an emotional affinity with kiai and pesantren tradition, but secular nationalist parties are also trying to make kiai their icon in winning the votes of the santris. ${ }^{8}$ A kiai functioned to give religious advice to society and then began to play the role of a political broker. The relationship of kiai with certain political parties makes the relationship between kiai and society not natural. Kiai does not just give advice but hopes that the community will

6 Clifford Geertz, "The Javanese Kijaji: The Changing Role of a Cultural Broker," Comparative Studies in Society and History, Vol. 2, No. 2 (January, 1960), 228-249.

7 Karl D. Jackson, Kewibawaan Tradisional, Islam dan Pemberontakan (Jakarta: Pustaka Grafika, 1990), 201.

8 Zainal Abidin Amir, Peta Islam Politik Pasca-Soeharto (Jakarta: LP3S, 2003), 2042. 
follow his political choices resulted from political transactions between the kiai and political parties.'

The kiais who maintain their function as cultural mediators in society are usually politically neutral. They give advices and prayers to everyone without any interest. Thus, the community still needs the position of this kiai, even though the number is getting smaller. Kiais who remain neutral in carrying out their functions to convey "the message of the sky" and serve the needs of society, in general, are usually known as "kiai langit" (kiai of the sky). People also know him as "kiai akbirat" (kiai of the afterlife). ${ }^{10}$

The decline in the influence of the kiai in society, in addition to the change in the role played by the kiai from the position of a cultural mediator to a political mediator, is also caused by internal changes in the pesantren which begins to modernize in response to social developments and changes in society. ${ }^{11}$ Modernization of pesantren allows for fundamental changes in the process of socialization and inheritance of pesantren traditions. ${ }^{12}$ The current phenomenon is that most kiais have limited experience of socialization. ${ }^{13}$ Socialization is understood as an individual process in learning values, norms, and teachings of life. The individual can be accepted by or becomes part of the community or group. The primary socialization media in pesantren are families, educational institutions, and informal meetings among pesantrens. The strength of the relationship between "senior kiai" and "young kiai" has decreased along with the limitations of socialization media carried out by kiai's successors. Most of the kiai's successors in

9 More details on how the kiai relates to politics can be found in Imam Suprayogo, Kyai dan Politik: Membaca Citra Politik Kyai (Malang: UIN Malang Press, 2007).

${ }^{10}$ Endang Turmudi, Perselingkuhan Kyai dan Kekuasaan (Yogyakarta: LKiS, 2004), $28-42$.

11 Anshori, "Kiai dan Otoritas Keagamaan: Potret Kehidupan Pesantren," Jurnal Penelitian dan Kajian Keagamaan, Vol. 31, No. 65 (July, 2004), 28.

12 Eka Sri Mulyani, Women and Pesantren Education: History, Kinship, and Contents: Negotiating Public Spaces (Amsterdam: Amsterdam University Press, 2012), 37-62.

13 In the research conducted by Arief Subhan, it is mentioned that the kiai's limitations in socialization in the modern era and the decline in individual competence are considered as one of the factors that cause the kiai's inability to deal with social changes and modernization, so that his role in society begins to erode. Arief Subhan, Lembaga Pendidikan Islam Indonesia Abad ke-20 (Jakarta: UIN Press, 2009), 129-135. 
modern pesantren have received formal religious education without going through the process of socialization and interaction between senior kiai and young kiai like in the tradition of classical authority transfer. ${ }^{14}$

The development of pesantrens in Central Java and East Java generally shows almost the same trend, while that in Banten and West Java provides different data. Therefore, in this article the discussion is focused on Pesantren Cidahu Pandeglang (Banten), Pesantren Husnul Khotimah Kuningan (West Java) and Pesantren Darul Ulum Jombang (East Java). This is because these three pesantrens represent different types of pesantren, namely traditional pesantren, modern pesantren, and semi-modern pesantren. What is meant by semi-modern pesantren here is a traditional pesantren which has been transformed into a modern pesantren.

To analyze the relationship between kiai and santri and their influences in society in relation to politics, it is necessary to use a theoretical basis on leadership and patron-client. This study focuses on the santri other than the community since the santri is the closest community to the kiai. If the relationship between kiai and santri experiences changes, it is assumed to affect the community level. In general, the role of the kiai is largely determined by his position as the leader of pesantren, although there are also other categories which state that some kiais do not have a pesantren. ${ }^{15}$

Weber divides leadership authority into three types, namely legal, traditional, and charismatic power. ${ }^{16}$ The theory of charismatic leader, which sees the legitimacy of leadership as rooted in a person's charisma and unique qualities and the recognition of others for it, can be used as a basis for analysis. In this case, the charismatic authority of kiai in three pesantrens shows a decline due to the effects of modernization. Meanwhile, the patron-client theory will help in seeing the extent of the relationship between kiai and santri. In looking at this relationship,

\footnotetext{
${ }^{14}$ M. Dian Nafi et al., Praksis Pembelajaran Pesantren (Yogyakarta: Yayasan Selasih, 2007).

15 Dhofier, Tradisi Pesantren, 50.

16 Ayub Ranoh, Kepemimpinan Kharismatis: Tinjauan Teologis-Etis atas Kepemimpinan Soekarno (Jakarta: BPK Gunung Mulia, 1999), 51-52.
} 
it is necessary to pay attention to the reinforcing factor of a person being positioned as a patron. Clients' dependence, especially in meeting material needs, makes the patron's position even more vital. ${ }^{17}$ Field research that the author conducted in 2013-2014 and updated in 2019-2020 with interviews and survey methods conducted in three pesantrens, namely Pesantren Darul Ulum Jombang, East Java, Pesantren Cidahu, Pandeglang, Banten, and Pesantren Husnul Khotimah, Kuningan, West Java, shows the results of the dependence level of students on different kiais. In modern and semi-modern pesantren, the dependence of santri on the kiai is decreasing, while in traditional pesantren, kiai as patron is still very strong.

Many studies have been carried out on the relationship between kiai and politics. However, some existing researches have not explicitly focused on looking at the perceptions of santri towards kiai in pesantren. The relationship between kiai and santri depicted from santri's views and attitudes towards the kiai is an essential element in seeing the extent to which the influence of kiai in terms of politics in society is still solid or vice versa. The following are some books that specifically discuss the figure of kiai in politics and how the author places his research in the existing scientific treasury.

Imam Suprayogo wrote a book entitled Kyai dan Politik; Membaca Citra Politik Kyai. In his research, Suprayogo concludes that the involvement of kiai in politics causes a prolonged polemic. Likewise, politicians often use kiai to facilitate their path to power, although not a few kiai are involved in practical politics. The involvement of kiai in politics has indirectly reduced the image of the kiai in front of his people. This paper does not discuss the perception of santri towards kiai.

Arief Subhan wrote a book entitled Lembaga Pendidikan Islam Indonesia Abad Ke-20: Pergumulan Antara Modernisasi dan Identitas. In general, Subhan argues that modernization has forced Islamic educational institutions, including pesantrens, to adapt through curriculum changes and relations with the government. The government is very interested in religious education institutions by providing financial assistance. Some pesantrens still maintain their

17 Maswadi Rauf, Konsensus dan Konflike Politike (Jakarta: Direktorat Jenderal Pendidikan Tinggi, 2001), 102. 
independence to maintain and spread their religious ideology. However, the pesantren inability to survive the challenges of modernization has forced them to compromise with the situation and cooperate with many parties, including the government. Here internal factors are very influential on changes in pesantren. There are traditional pesantren that remain firm with their identity, some have turned into modern pesantren, and some have been called modern from the start. The changes that occur in the santri element get less attention in this book.

Another book written by Ahmad Munjin Nasih is entitled Pudarnya Relasi Kiai-Santri. This book highlights the fading relationship between kiai and santri, which used to be very special and close. This study stated that the pattern of relationships, that is, sami'na wa at a'na (we hear and we obey), has shifted over time. The students and alumni did not fully follow some of the fatwas issued by the pesantren. Although Nasih has explained the shift in the pattern of relations, he did not specifically distinguish what type of pesantren the change occurred in. Likewise, the author does not explicitly describe the views of the santri towards kiai.

In addition to the literature review, data collection methods in this study were carried out by direct observation, interviews, and surveys. Research activities were carried out in several large and influential pesantrens in Java, namely Pesantren Cidahu in Pandeglang, Banten, Pesantren Husnul Khotimah in Kuningan, West Java, and Pesantren Darul Ulum in Jombang, East Java. The research results will be classified into two essential discussions: the relationship between kiai and santri (kiai, pondok and curriculum) and the perception of the santri towards the kiai. The development of the three types of pesantren that are the object of this research shows different and interesting characteristics in terms of the kiai's figure, the pondok, and the curriculum.

The survey was conducted on the male and female santris in the three pesantrens. The number of questionnaires distributed was 100 for each pesantren divided into 50 male and 50 female santris. As the santris are the closest community to kiai, the influence of kiai can most easily be measured from the views of the santri towards him. Therefore, if the santri's perception of the kiai has changed, the general public's perception of the kiai will, for sure, also change. 


\section{The Characteristic of the Three Pesantrens}

Social changes have encouraged traditional pesantrens to make adjustments to maintain their existence. These changes were carried out by implementing the modernization of pesantren. Pesantren that make modifications to respond to outside developments are usually known as Semi-modern Pesantrens, which combine the old traditions of pesantren and modern values. However, some pesantrens still maintain their authenticity as traditional pesantren (Salaf). ${ }^{18}$ Pesantren salaf is different from the contemporary pesantren salafi that in somehow some of them are suspected to be involved in radical violent activism in Indonesia. ${ }^{19}$

Pesantren Cidahu is one of the pesantren that still maintains its characteristics as a traditional pesantren and does not carry out the modernization process. In contrast, since its inception, the Pesantren Husnul Khotmah has been oriented towards the development of modern pesantren. Meanwhile, Pesantren Darul Ulum, although still maintaining traditional characteristics, has made many developments that lead to modernization (semimodern). Therefore, the three types of pesantren have different characteristics and place the function of the kiai, which also tends to differ in terms of authority. In this study, the differences between the three types of pesantren, their relation to the influence of the kiai, and the perceptions of the santris began to be seen. Below, the characteristics of the three pesantrens in relation to the position of the pesantren, santri, and the pesantren curriculum will be analyzed.

\section{The Position of Kiai}

In Pesantren Cidahu, the figure of the kiai still occupies a central and very important position. Kiai is highly respected and all his words become a guide for the students. This characteristic of the kiai cannot be separated from the condition of the pesantren which maintains the traditional model in which the kiai is a very central part of the life of the pesantren. The figure of a very charismatic kiai was originally built by $\mathrm{H}$. Muhammad Dimyati (d.

\footnotetext{
18 Interview with Kiai Matin, Pandeglang, July 13, 2018.

19 V. Arianti, "Participation of Children in Terrorist Attacks in Indonesia: A Possible Future Trend," Counter Terrorist Trends and Analyses, Vol. 10, No. 11 (November, 2018), 4-8.
} 
2003), who was usually called Abuya Dimyati. The development of the religious authority of Abuya Dimyati was then continued by his children. The current successor to Abuya Dimyati who is considered quite influential is Kiai Muhtadi and Kiai Murtadlo. At Pesantren Cidahu, these two kiais have a pengajian (study forum) attended by various levels of society around the pesantren and even outside the city. Kiais in this pesantren have a special relationship with the people who come to him to get direction and guidance in life. ${ }^{20}$

At Pesantren Husnul Khotimah as a modern pesantren, the figure of kiai is placed as an ustadh. The role of kiai is spread over the ustadhs who teach at the pesantren. Leadership is not monopolized by one kiai but is carried out collectively. Even this pesantren does not know the term "kiai" rather than "ustadh." The leadership of the pesantren is determined by a foundation, selected according to the term of office, and can be rotated by the existing ustadhs. Relationships with santri are more formal so that kiai/ustadh is not a central figure. In society, the ustadhs of this pesantren do not have a profound influence because no surrounding community comes to the pengajian activities at this pesantren. Instead, students and pesantren interact with the community in the form of social activities and community service.

At Pesantren Darul Ulum, the leadership of the pesantren is held by the pesantren assembly, chaired by a senior kiai. Supervision is carried out collectively by accommodating the descendants of the founders of the pesantren. This pesantren was founded by Kiai Tamim Romli in 1889 who had three children who became separate descendants in the pesantren. The three descendants who represent the leadership in this pesantren are from the descendants of Kiai Romli represented by three people, Kiai Umar by three people, and Kiai Kholil by two people. Unlike the descendants of Kiai Romli and Kiai Umar who were represented by three people in the pesantren assembly, the descendants of Kiai Kholil were only represented by two people because he was the son-in-law of Kiai Tamim. In Islamic tradition, women get a smaller share than men.

In general, the kyai's leadership figure is no longer centralized because it has been divided into kiai's assemblies. The existence of

${ }^{20}$ Interview with Kiai Murtadlo, Pandeglang, July 2013, 2018. 
kiai in pesantren is also not dominated by a single kiai figure. At Pesantren Darul Ulum, there are currently 28 dormitories, each of which is managed autonomously by family members of the children and grandchildren of the founders of the pesantren. Each dormitory has a locale that tends to be separate from the others. The students will usually interact with students from other dormitories when they study in formal schools in the pesantren.

\section{Pondok and Santri}

Pondok (boarding/cottage) is a residence for santris in pesantren. In this place, the students sleep, study, and interact with others. Most of the santris stay in the pondok, although there are also so-called bats santris who only come during the day and return at night to their respective homes. The condition of the pondok is different from one pesantren to another.

In Pesantren Cidahu, pondok is called kobong, a simple "building" that is usually made of boards and a straightforward thatched roof. Some of these kobongs are inherited from the senior students, but some are built by the students themselves and are usually brought directly by them. The kobong can be occupied by 10-20 santris without a particular room. Here is where the santris experience a simple life and fulfil their daily needs. Since they are not set a monthly fee, most of the santris at Pesantren Cidahu live simply. They usually cook for themselves, help the kiai's activities such as gardening or take care of daily needs at the kiai's house. Until now, kobong is left natural and not much change. Most of the santris came from farmers and traders families around Banten, some from East Java and even outside Java who had a special relationship with the pesantren. Most of them want to be teachers or religious leaders in the community. The number of santris in this pesantren is about 300 people. $^{21}$

At Pesantren Husnul Khotimah, pondok is more similar to a high school student dormitory or university student dormitory where the students' rooms are occupied by a limited number of two to four people. They do not carry out daily activities independently but are used to employing people around the pondok. For example, they do not need to wash or cook for themselves because they are used to the laundry and catering

${ }^{21}$ Interview with Kiai Muhtadi, Pandeglang, July 13, 2018. 
provided by the pesantren. They also do not need to help the needs of the kiai in the pesantren because they usually pay a higher fee than the Pesantren Cidahu. Interaction with kiai, the pesantren leaders, is very rare because they do not make him a charismatic figure but rather an educator and companion role. Compared to Pesantren Cidahu, the number of santris in this pesantren is very large because it reaches 2500 people. $^{22}$

Meanwhile, Pesantren Darul Ulum has developed a dormitory that tends to implement an autonomous system. About 28 dormitories built in the pesantren complex are managed independently by the kiai's families. Each dormitory organizes pengajian independently, especially in terms of pengajian of kitab kuning (yellow books). The kitab kunings studied in each dormitory have been determined by the central board of Pesantren Darul Ulum. Still, for the determination of the ustadh (teachers), it is left to each dormitory. The dormitories follow a modern model and are equipped with several facilities, such as catering, laundry, and study rooms. Each room is usually filled with about five to ten santris. Each dormitory has a different management model. Some are simple, but some are relatively luxurious by implementing a guesthouse model. A dormitory is named Hurrun Inn, and a waiting area is called the dormitory lobby. Of course, this condition is much different from the traditional pesantren model. The number of students reached 8000 people. ${ }^{23}$

\section{The Curriculum}

The curriculum in each of the three pesantrens is quite different. Nevertheless, it has characteristics and represents the diverse interests of santri. Semi-modern pesantren usually has similarities with traditional and modern pesantren in certain aspects of the curriculum, while modern and traditional pesantren show the salient difference.

In Pesantren Cidahu, the education curriculum follows the religious education model inherited by the pesantren founders and does not have much change. The santris particularly come to kiai's home based on the schedules and kitab (books) which will be studied. Interaction between kiai and santri then becomes very

\footnotetext{
22 Interview with Ustadh Ahmad, Kuningan, August 27, 2019.

${ }^{23}$ Interview with Zaemuddin Asad, Jombang, September 14, 2020.
} 
close and allows the santri to get to know the kiai more deeply. Santri also treats the kiai as the central figure in conveying religious messages. There is no general curriculum, and even the curriculum does not follow the religious curriculum set by the Ministry of Religious Affairs. Instead, the santris are educated to master certain kitab and to practice them in society. The teaching and learning activities in the pesantren use sorogan model where the santris sit to listen to the kiai's speeches.

Pesantren Darul Ulum develops modern curriculum. In this pesantren, there are various models of education, from primary to university level. This pesantren adopts the curriculum set by the Ministry of Education and Culture. The learning material delivered at the school program balances religious dan non-religious sciences. There are some high education levels deliberately set up to develop (non-religious) science and technology. Among them are the well-known SMA Unggulan Darul Ulum, SMK Telkom, and Universitas Darul Ulum. ${ }^{24}$

Almost the same as Pesantren Darul Ulum, Pesantren Husnul Khotimah Kuningan, which since its inception claims itself as modern pesantren, develops the curriculum similar to that of $\mathrm{Al}$ Azhar, Egypt. Although non-religious sciences are taught in this pesantren, their credit is not as high as religious sciences. This condition cannot be separated from the fact that most of the santris want to continue their religious education both at home and in the Middle East. The curriculum set up by the Ministry of Religious Affairs is also adopted and adapted to that of Al-Azhar. Even though the pesantren still maintains pesantren education system, yet because it embraces the modern one, the relationship between santri and kiai in this pesantren is pretty loose, unlike in Pesantren Cidahu and Pesantren Darul Ulum. ${ }^{25}$

\section{Kiai's Authority and Santri's Perception towards Kiai}

Modernization has changed not only the kiai-santri relationship but also the community's need for pesantren. Pesantren is no longer seen as an educational institution that provides religious education only, but more than that, as an alternative to public schools. Parents of the santris send their children to pesantren no

\footnotetext{
${ }^{24}$ Interview with M. Dzul Azmi, Jombang, September 14, 2020.

25 Interview with Ustadh Abdurahman, Kuningan, August 27, 2019.
} 
longer to study religious sciences but to access the quality education offered. This condition happened when pesantren began to develop a modern education system. Some pesantren also starts to focus certain skill in Islam, such as in calligraphy. ${ }^{26}$ The santris also want to master non-religious knowledge and hope to continue to well-known universities or get their dream job according to the needs of the of workplaces. ${ }^{27}$ The influence of the kiai, who used to rely on the networks of pesantren and alumni who were constantly attached to the pesantren informally, was reduced because there were no santri agents who continued the authority of the kiai. ${ }^{28}$

The interesting thing analyzed in this section is how the santris' perceptions of the kiai in the three pesantrens describe the pesantren model in general. There are striking differences between the attitudes of santris in traditional, semi-modern, and modern pesantren. Traditional pesantren were represented by Pesantren Cidahu Pandeglang, semi-modern pesantren by Pesantren Darul Ulum Jombang, while modern pesantren by Pesantren Husnul Khotimah Kuningan.

Traditional pesantrens in Indonesia show a general tendency that the authority of the kiai tends to be high. The influence of the kiai in the pesantren is relatively strong because the pesantren tradition is well-maintained. For a more specific case, Pesantren Cidahu represents traditional pesantren in terms of buildings, curriculum, and relations between kiai and santri. Semi modern and modern pesantren experienced a rapid decline in the authority of kiai. Semi-modern pesantren still adopts the pesantren tradition inherited by the founders of the pesantren even though they have transformed into a modern educational institution. Supervising patterns remain unchanged, and the characteristics of traditional pesantren are still visible. At Pesantren Darul Ulum, Jombang, the authority of kiai is still relatively strong due to the existence of tarekat practices that continue to preserve. Kiai Dimyathi, the

\footnotetext{
${ }^{26}$ Virginia Hooker, "By the Pen! Spreading 'Ilm in Indonesia through Quranic Calligraphy," in Samer Akkach (ed.), Science, Religion and Art in Islam (Adelaide: University of Adelaide Press, 2019), 88-89.

27 Mujamil Qomar, Pesantren: Dari Transformasi Metodologi Menuju Demokratisasi Institusi (Jakarta: Erlangga, 2006), 42.

28 Turmudi, Perselingkuban Kyai, 28-42.
} 
caretaker of the pesantren and the Chairman of the pesantren assembly, also serves as a murshid of the Tarekat Qadiriyah wa Naqshabandiyah. Meanwhile, Pesantren Khusnul Khotima, from the beginning, has positioned itself as a modern pesantren to distinguish it from traditional pesantren. Many of the practices applied in traditional pesantren, such as submission to the kiai taqlid (totally following) and excessive loyalty, often get criticism from modern pesantren's point of view. In fact, it is these practices that can perpetuate the influence and authority of kiai in pesantren.

Perceptions and attitudes towards kiai will be explained through a survey given to the santri in the three pesantren models. Traditional pesantrens, in general, tend to show strong attitudes towards kiai, while semi-modern and modern pesantrens do otherwise.

\section{Traditional Pesantren}

In traditional pesantren, there are similarities in terms of the origin of the santris and their parents' occupations. Regarding the selection of the pesantren, it is largely influenced by the presence of relatives (family) or old friends who have studied or are currently studying at the pesantren concerned. In this type of pesantren, most of the santris come from the local area. Although there are from outside the district and even outside Java, but the number is relatively small. Usually, those outside Java still have family relationships and friendships with those who have studied at the pesantren. Therefore, in this pesantren, the number of students from farmers and small traders families is still relatively large.

For sure, in terms of motivation to learn in pesantren, they are more influenced by parents, relatives, and friends than their desires. This condition can be seen from the number of their relationships with santris who are studying at, or have graduated from, the pesantren. From the survey, it appears that about $74 \%$ of students studying have relatives who have studied or are studying at this pesantren while $26 \%$ do not. Furthermore, the influence of friends from one area is also influential in providing information about the existence of pesantren and in making students want to study at traditional pesantren because $89 \%$ of santris have old 
friends who have studied or are studying at the pesantren. Only $11 \%$ have no friends at all. For more details, see the following table.

Table 1. Are there any relatives/friends who have studied at this pesantren?

\begin{tabular}{llll}
\hline Relatives & Percentage & Friends & Percentage \\
\hline Yes & $74 \%$ & Yes & $89 \%$ \\
No & $26 \%$ & No & $11 \%$ \\
Total & $\mathbf{1 0 0} \%$ & Total & $\mathbf{1 0 0} \%$ \\
\hline
\end{tabular}

Uniquely, there is a shift in the influence of kiai in directing students to choose a pesantren. Santris pay more attention to the existence and greatness of the name of the pesantren than to the influence of the kiai figure. This means that the pesantren is no longer attached to the figure of the kiai but rather to the institution's existence. Perhaps this is because most traditional pesantrens have switched to the second, third, and fourth generations. The name of the kiai is no more popular than the name of the pesantren itself. The next choice is determined by the parents and therefore influenced by the big name of the kiai. A survey data shows that $51 \%$ of santris choose to study at Pesantren Cidahu because of the great name of the pesantren, $31 \%$ because of following their parents, $10 \%$ because of the alumni success factor, and only $8 \%$ because of the kiai figure. However, in general, they greatly admire the kiai and make the kiai a figure who must be respected.

Table 2. Why did you choose this pesantren?

\begin{tabular}{ll}
\hline Factors & Percentage \\
\hline Parents & $31 \%$ \\
The kiai figure & $8 \%$ \\
The great name of the pesantren & $51 \%$ \\
Alumni success & $10 \%$ \\
Total & $\mathbf{1 0 0} \%$ \\
\hline
\end{tabular}

Does this admiration impact the current strength of the kiai's authority in the fields of religion and politics? Is the influence of the kiai in the religious and political areas still strong and makes him a figure who is always followed? In general, santris in 
traditional pesantren follow the orders of the kai. Still, it is starting to appear that there is a possibility of different opinions, especially in terms of religious knowledge and political aspirations. However, the kiai's authority in religion and politics is still very decisive. Therefore, only a few have different opinions or have different aspirations from the kiai. The following table shows the tendency of students in traditional pesantren based on a survey conducted on students at Pesantren Cidahu.

Table 3. Is it permissible to be different from the kiai in terms of religious knowledge or political choices?

\begin{tabular}{llll}
\hline $\begin{array}{l}\text { Different } \\
\text { opinions }\end{array}$ & Percentage & $\begin{array}{l}\text { Different political } \\
\text { choices }\end{array}$ & Percentage \\
\hline Yes & $37 \%$ & Yes & $13 \%$ \\
No & $56 \%$ & No & $79 \%$ \\
Do not know & $7 \%$ & Do not know & $8 \%$ \\
Total & $\mathbf{1 0 0 \%}$ & Total & $\mathbf{1 0 0 \%}$ \\
\hline
\end{tabular}

Semi-modern Pesantren

Pesantren Darul Ulum in Jombang shows a different phenomenon from that of traditional pesantren. The origin of the santri is still dominated by the districts around the pesantren, which are mostly from East Java, but there are also those from outside Java. In terms of the occupational background of the parents of santris, most of them are dominated by families with self-employed jobs, civil servants, and only a few are from farming families. This condition is very different from traditional pesantren, dominated by farming families and small traders, because it is closely related to additional educational costs.

From the side of kinship and friendship, it appears that there is a similarity with that in semi-modern pesantren. Most of the santris have relatives or friends who have studied or are currently studying at the pesantren. This relationship makes them want to stay in the pesantren because there is still an emotional connection with other students. unlike in traditional pesantren where parents factor is still decisive in determining the choice for santris to study in pesantren, in semi-modern pesantren, the awareness to make their own choices is more vigorous. As many as $65 \%$ of santris choose Pesantren Darul Ulum because of their own choosing, and $35 \%$ because they follow their parents' choices. The factors that 
determine the choice are mostly due to the great name of the pesantren, the parents' influence, the alumni success story, and a little because of the kiai figure.

Table 4. Why did you choose this pesantren?

\begin{tabular}{ll}
\hline Factors & Percentage \\
\hline Parents & $25 \%$ \\
The kiai figure & $4 \%$ \\
The great name of the pesantren & $59 \%$ \\
Alumni success & $11 \%$ \\
Total & $\mathbf{1 0 0} \%$ \\
\hline
\end{tabular}

The possibility of different opinions in matters of religion in semi-modern pesantren is starting to open up. Santris are no longer afraid to have different views as long as they have a solid argument base. As such, in terms of politics, santris are also more concerned with their rational choices than simply following the kiai's political decisions. The following table shows possible differences of opinion in terms of religion and political choices between kiai and santri in semi-modern pesantren.

Table 5. Is it permissible to be different from the kiai in terms of religious knowledge or political choices?

\begin{tabular}{llll}
\hline $\begin{array}{l}\text { Different } \\
\text { opinions }\end{array}$ & Percentage & $\begin{array}{l}\text { Different } \\
\text { political } \\
\text { choices }\end{array}$ & Percentage \\
\hline Yes & $91 \%$ & Yes & $80 \%$ \\
No & $6 \%$ & No & $13 \%$ \\
Do not know & $3 \%$ & Do not know & $7 \%$ \\
Total & $\mathbf{1 0 0} \%$ & Total & $\mathbf{1 0 0} \%$ \\
\hline
\end{tabular}

\section{Modern Pesantren}

Pesantren Husnul Khotimah Kuningan does not have traditional roots. This pesantren was founded in the 1990s but had many santris compared to the average pesantren in West Java. The number of santris reaches around 2500 coming from various regions in and outside Java. From the parents' background, most of the santris registered at this pesantren are from upper-middleclass families that work mostly as entrepreneurs and civil servants. 
This is, of course, very closely related to the relatively high cost of education compared to other existing pesantrens.

The similarity of modern pesantren with traditional and semimodern pesantren lies in the tendency of santris to have kinship within the pesantren and emotional connection. This means that most of santris have relatives or friends who have studied or are studying at the pesantren in question. This aspect almost exists in every pesantren, be it traditional, semi-modern, or modern pesantren. On the other hand, the education model that is relatively exclusive and seems strange to santris who will study at the pesantren makes those who have never had an emotional relationship with the pesantren do not dare or are reluctant to learn at the pesantren.

The reason why the santris choose to study at the pesantren is still dominated by the greatness of the pesantren's name, the wishes of parents and alumni. The kiai figure factor is minimal because the leadership in modern pesantren usually follow modern management where kiais are selected and appointed by regulations of the foundation. Therefore, in general, the figure of the kiai is less well-known, and the name of the institution is much better known than that of the kiai himself. This is very different from the traditional pesantren, which relies on the figure of the kiai. The following table explains the crucial factors for students to choose to study in modern pesantrens.

Table 6. Why did you choose this pesantren?

\begin{tabular}{ll}
\hline Factors & Percentage \\
\hline Parents & $37 \%$ \\
The kiai figure & $1 \%$ \\
The great name of pesantren & $41 \%$ \\
Alumni success & $12 \%$ \\
Total & $\mathbf{1 0 0} \%$ \\
\hline
\end{tabular}

The more open modern pesantren life with different backgrounds of santris, including relatively high social status in society, makes the santris prioritize rational choices in viewing the figure of a kiai. In general, they respect and admire the kiai figure but are not focused on one kiai, not on the figure but rather on the roles of the kiai. This tendency will appear in the choice of 
following the kiai as long as the choice is in accordance with the wishes and thoughts of the santris.

What about the influence of the kiai in directing religious attitudes and political choices in general? Santris at Pesantren Husnul Khotimah considers that differences of opinion in religious matters are permissible as long as supported by adequate arguments (96\%) and do not show any hesitation (4\%). Surprisingly, no santris think that santris should not have different opinions with the kiai $(0 \%)$. Regarding political choices, only about $3 \%$ of santris believe that their choices must follow the kiai's choices while $94 \%$ think to do not have to be the same as the kiai's choices, and another $3 \%$ express doubts.

Table 7. Is it permissible to be different from the kiai in terms of religious knowledge or political choices?

\begin{tabular}{llll}
\hline $\begin{array}{l}\text { Different } \\
\text { religious opinion }\end{array}$ & Percentage & $\begin{array}{l}\text { Different } \\
\text { political choices }\end{array}$ & Percentage \\
\hline Yes & $96 \%$ & Yes & $94 \%$ \\
No & $0 \%$ & No & $3 \%$ \\
Do not know & $4 \%$ & Do not know & $3 \%$ \\
Total & $\mathbf{1 0 0 \%}$ & Total & $\mathbf{1 0 0} \%$ \\
\hline
\end{tabular}

\section{Conclusion}

In general, traditional pesantren inherits the characteristic of "old pesantren" from generation to generation without any changes. In terms of both religion and politics, the authority of kiai in this kind of pesantren remains strong, even though nowadays it experiences a little change. Traditional pesantrens in general, and those in Banten in particular, have several santris limited in the range of hundreds.

The semi-modern pesantren, a pesantren in transition from the traditional to the modern one, also shows an interesting phenomenon: trying to do modernization and slowly teaching new methods while still maintaining some pesantren traditions, especially in matters of parenting. In terms of curriculum and facilities, this pesantren has developed itself a more modern one. The relationship between the kiai and the santri in this pesantren is not as intimate as that in traditional pesantrens, so that it results in a decrease in the authority of the kiai. 
Modern pesantren, since its inception, has implemented a modern system. It emerges as a reaction to the traditional pesantrens considered as being lack of development. The relationship between santri and kiai in this pesantren is but a formal relationship in education. In contrast, the role of the kiai is not focused on one figure but distributed to many ustadhs in the pesantren. Due to the absence of the kiai as the central figure, the relationship between the santri and the kiai generally becomes loose and certainly affects the santris' perception towards the kiai. The kiai in this pesantren does not have full authority because the leadership and management of the pesantren follow government regulations regarding the establishment and discipline of a foundation.

Modernization of pesantren has also encouraged pesantren to develop a model of education needed by the community. Pesantren is no longer a place for santris who want to master the religious sciences and develop their knowledge by establishing a new pesantren after their coming back to the society. Instead, the pesantren have begun to introduce a formal and modern education system by adopting a national education system and emphasizing the importance of mastering skills and non-religious sciences. Thus, the interaction between kiai and santri is getting lower, because the function of the kiai has been replaced by that of ustadhs in the pesantren.

\section{Bibliography}

\section{Books and Articles}

Amir, Zainal Abidin. Peta Islam Politik Pasca-Soeharto. Jakarta: LP3S, 2003.

Anshori. "Kiai dan Otoritas Keagamaan: Potret Kehidupan Pesantren," Jurnal Penelitian dan Kajian Keagamaan, Vol. 31, No. 65, July 2004.

Arianti, V. "Participation of Children in Terrorist Attacks in Indonesia: a Possible Future Trend," Counter Terrorist Trends and Analyses, Vol. 10, No. 11, November 2018.

Bashori. "Modernisasi Lembaga Pendidikan Pesantren Perspektif Azyumardi Azra," Nadwa: Jurnal Pendidikan Islam, Vol. 11, No. 2, 2017. 
Dhofier, Zamakhsysari. Tradisi Pesantren: Studi tentang Pandangan Hidup Kyai. Jakarta: P3M, 1982.

Geertz, Clifford. "The Javanese Kijaji: The Changing Role of a Cultural Broker," Comparative Studies in Society and History, Vol. 2, No. 2, January 1960.

Haryatmoko. Dominasi Penuh Muslihat: Akar Kekerasan dan Diskriminasi. Jakarta: Gramedia, 2010.

Hooker, Virginia. "By the Pen! Spreading 'Ilm in Indonesia through Quranic calligraphy," in Samer Akkach (ed.), Science, Religion and Art in Islam. Adelaide: University of Adelaide Press, 2019.

Jackson, Karl D. Kewibawaan Tradisional, Islam dan Pemberontakan. Jakarta: Pustaka Grafika, 1990.

Mastuhu. Dinamika Sistem Pesantren. Jakarta: INIS, 1994.

Nafi, M. Dian et al. Praksis Pembelajaran Pesantren. Yogyakarta: Yayasan Selasih, 2007.

Mulyani, Eka Sri. Women and Pesantren Education: History, Kinship, and Contents: Negotiating Public Spaces. Amsterdam: Amsterdam University Press, 2012

Nizar, Samsul. Sejarah Sosial dan Dinamika Intelektual: Pendidikan Islam di Nusantara. Jakarta: Kencana Prenada Media Group: 2013.

Qomar, Mujamil. Pesantren: dari Transformasi Metodologi Menuju Demokratisasi Institusi. Jakarta: Erlangga, 2006.

Ranoh, Ayub. Kepemimpinan Kharismatis: Tinjanan Teologis-Etis atas Kepemimpinan Soekarno. Jakarta: BPK Gunung Mulia, 1999.

Rauf, Maswadi. Konsensus dan Konflik Politik. Jakarta: Direktorat Jenderal Pendidikan Tinggi, 2001.

Subhan, Arief. Lembaga Pendidikan Islam Indonesia Abad ke-20. Jakarta: UIN Press, 2009.

Suprayogo, Imam. Kyai dan Politik: Membaca Citra Politik Kyai. Malang: UIN Malang Press, 2007.

Turmudi, Endang. Perselingkuhan Kyai dan Kekuasaan. Yogyakarta: LKiS, 2004.

\section{Interviews}

Kiai Muhtadi, Pandeglang, July 13, 2018.

Kiai Murtadlo, Pandeglang, July 13, 2018.

Kiai Matin, Pandeglang, July 13, 2018. 
Ustadh Abdurahman, Kuningan, August 27, 2019.

Ustadh Ahmad, Kuningan, August 27, 2019.

M. Dzul Azmi, Jombang, September 14, 2020.

Zaemuddin Asad, Jombang, September 14, 2020. 